\title{
Ethics for everyday heroes - from Utilitarianism to Effective Altruism
}

\author{
Jakub Synowiec
}

\begin{abstract}
Effective Altruism is a very new discipline. The first steps towards creating a community were made in 2009. Although the movement is young, it has already changed lives of many people and its popularity continues to rise. The idea of effective altruism is deeply rooted in philosophy, hence to understand it better an attempt will be made to reconstruct and present the philosophical framework of Effective Altruism. This part is intended to show the development of utilitarian thought that led to Effective Altruism. I intentionally limited this reconstruction to the views of Peter Singer, as his philosophy inspired many effective altruists, especially at the beginning of the movement. I have tried to show that his earliest works were the first steps on the way to effective altruism. In the second part selected details of the idea will be referred to in order to show the current state of development of this branch of utilitarianism. In the last part, selected doubts and critical remarks will be presented that might be inspiration to adapt Effective Altruism to specific conditions of Central and Eastern Europe. It will be argued that advocacy for Effective Altruism is a fair way for effective altruists in countries of Central and Eastern Europe.
\end{abstract}

Keywords: Effective altruism, Peter Singer, charity

\section{Introduction}

In the most affluent countries, the $21^{\text {st }}$ century is a period of prosperity. People are getting wealthier and wealthier, their lives are very comfortable; they have opportunities that were not available for the richest of their grandparents' generation. Affluence, comfortable life, no need for struggle, pushes people into consumerism - obtaining more and more goods without real need. Increasing consumption is expected to give satisfaction. There are, however, people who consider it futile. For them satisfaction is not to have, but to give, they are altruists. If an altruist has a consequentialist approach, he focuses not on the act of giving but on the effect of giving. People who want to achieve the best effects - considered from the impartial point of view - with available resources, are effective altruists.

Effective altruism is a philosophical idea which transformed into a social movement Effective Altruism. The aim of Effective Altruism is to make the world as good a place as is possible (MacAskill, 2015b, p. 11). If you consider it for an individual, his/her aim can be presented as "to do the most good you can". What exactly the most good means, is specified by philosophy. As the philosophy supporting Effective Altruism is mainly utilitarianism, many of its members understand "good" in a hedonistic sense. Effective altruism differs from "traditional" altruism because it is focused on the effectiveness of achieving its objectives. It is effective in its selection of targets: only "cost-effective" targets are chosen as targets for Effective Altruism. William MacAskill, one of the philosophers supporting Effective 
Altruism, presents its three ${ }^{1}$ targets: eradicating extreme poverty (which is also the UN millennial development goal), reducing suffering of animals and preventing extinction of life on Earth (MacAskill, 2015b, p. 12). The first of the targets of Effective Altruism was always a part of people's concern and was a part of practical ethics long before effective altruism was created. The two other targets were generally neglected and became treated as a major ethical problem only at the end of the $20^{\text {th }}$ century. ${ }^{2}$ The difference that Effective Altruism makes comes from the application of science to our emotional need of helping. Researchers evaluate charity programs in order to choose the most effective ones; the most effective programs are supported by the Effective Altruists' community. And as effective altruists show, there is a great difference between the most effective organizations and just effective organizations, so donating to the former and not the latter makes a significant difference. MacAskill shows an example, where "the best healthcare programme is estimated to be five hundred times more effective than the worst (which, remember, is still a good programme)" (MacAskill, 2015a, pp. 62-64).

Before I present effective altruism as an ethical proposition for contemporary people, I find it important to focus on its philosophical framework. Although the movement is very young, it is deeply rooted in philosophy, especially in utilitarian practical ethics. Reconstructing its philosophical roots is important in order to understand it. I intentionally limit my analysis to the philosophy of Peter Singer, who inspires many effective altruists and has been an important person for the movement from the very beginning. Many other philosophers supporting the idea are Singer's followers. It must be emphasized, though, that Effective Altruism cannot be limited to Singer's thinking or even to utilitarianism; the movement is much broader and open for new ideas and the idea of effective altruism is developed by people with different philosophical backgrounds. On the other hand, Effective Altruism owes a lot to Singer and utilitarian philosophy. The viewpoint I propose is just a methodological tool to introduce the topic, not an attempt to grasp or classify the whole movement.

After presenting effective altruism, an attempt will be made to analyse whether this it is a good proposition for "everyday heroes" in countries of Central and Eastern Europe, like Poland and Slovakia. I try to emphasize some difference that may impact the development of effective altruism in these countries and suggest that advocacy for Effective Altruism is a worthy strategy for effective altruist in less-wealthy nations or areas where this idea is unknown.

\section{Utilitarian roots}

Many people important to Effective Altruism in its early stage of development were Utilitarians. People sharing this philosophical position believe, in short, that the best actions lead to the greatest happiness for the largest number of conscious beings. It should be done by

\footnotetext{
${ }^{1}$ There is a debate among effective altruists, regarding the targets. MacAskill calls them "our best guesses" and claims that "[I]f we had good evidence or arguments that showed that we could do more good by doing something else, then we'd do that instead" (MacAskill, 2015b, pp. 11-12). Peter Singer devotes a chapter of his book for each of these cases, however when considering preventing life extinction, he focuses on humans (Singer 2015). On the other hand, Luke Muehlhauser argues there are four areas of activity of Effective Altruism: poverty reduction, meta-effective altruism, the far future of people and animal suffering (Muehlhauser, 2015). Effective altruists generally agree that many traditional areas of charity, like education, art, aiding victims of catastrophes or supporting the local community, are not the targets of Effective Altruism (Singer, 2015, pp. 89, 107-136; MacAskill, 2015a, pp. 222-242).

2 These two targets are not universally perceived as important areas in ethics. Redirecting resources from the needs of people to the needs of animals or to support research on preventing possible catastrophes is sometimes a source of critique of Effective Altruism. The Oxford philosopher Nick Bostrom argues that on the basis of calculations, the third area is also the most important one, and the highest priority should be put on preventing human extinction, because the number of people living now is very small compared to the number of their descendants that might be living in the future (Bostrom, 2013).
} 
eradicating pain and adding pleasure to beings' lives. Avoiding pain and following pleasure seems to be a worthy strategy. Bentham explained in a clever way; that it is hard to imagine someone willing to take the opposite one, basically, all of us, avoid pain and prefer pleasure (Bentham, 1789, chapter. 1). The philosophical discussion is, as usual, when we go deeper and try to clarify notions. A utilitarian must know the answers to questions like: what is pain, what is pleasure, whose pleasure counts and how to achieve the greatest happiness of the largest number of beings?

One of the fathers of Effective Altruism and a declared utilitarian, Peter Singer, had to answer the same questions. His philosophical inquiries, presented in many books and shorter texts, reveal his answers. From the very beginning of his philosophical career, he struggled to make philosophical justification for eradicating pain of animals and to propose a good reasoning to convince people to improve the quality of life of those living in extreme poverty. He admits that these two topics always were the most important to him and that he intentionally focused on them, as they were neglected (Singer, 2000, pp. xiv-xv).

In his main work, Practical Ethics, Singer formulates the fundamentals of his philosophical thinking and claims that what counts in utilitarian calculations are interests, namely, what a being may desire (Singer, 1979, p. 12). Although he uses a genuine term, "interests", his ethics remains hedonistic as for him the ability to feel pain is a minimum requirement for a being to be considered as having interests (Singer, 1979, p. 50). The more conscious a being is the more interests it has. But, in Singer's ethics, all sentient beings are equal - the interest of a being is equal to the same interest of another being - says the rule of equal consideration of interests introduced by Singer (Singer, 1979, p. 19).

Based on this, Singer claimed it is wrong to neglect the interests of animals for the sake of the interests of people. He noticed that the great majority prefers the trivial interests of people (like better tasting or cheaper food) to the crucial interests of animals (life, life without pain). He even famously popularized a name to such an attitude: speciesism. By his early works (Singer, 1975) he started a philosophical debate on our attitude to animals. His arguments convince many effective altruists to become vegans or struggle to reduce the suffering of animals.

The other most important topic for Singer was his philosophical concern for people living in extreme poverty. In his first article on practical ethics, Famine Affluence and Morality (Singer, 1972), he points out that we don't really seriously take into account the interests of people living in distant lands. In his article, Singer argues that people living in extreme poverty need help and providing this help will be cheap for us, but we are not moved to do it. We would rather help people from the same country or culture. Furthermore, we would rather help ourselves in less important needs than others in their crucial needs. For example, as Singer notices, the British government gave thirty times more money to improve hypersonic transportation (the Concorde programme) than to support people living in extreme conditions after a catastrophe in Bengal in 1971. For Singer, the way we react to peoples' suffering in distant countries cannot be justified from the point of view of ethics. In this short article, he formulated his famous argument that eradication of extreme poverty is a moral duty. Singer developed this argument in his further works, considering new circumstances, progress in science and in philosophy, for example Living High or Letting Die by Peter Unger (Unger, 1996) as well as philosophical critique. After about 40 years of philosophical reflection, one of the most prominent contemporary philosophers presented his argument as based on three premises: "suffering and death from lack of food, shelter, and medical care are bad"; "If it is in your power to prevent something bad from happening, without sacrificing anything nearly as important, it is wrong not to do so"; by donating to aid agencies, you can prevent the suffering mentioned in premise one on the conditions stated in premise two. The conclusion of the argument is "if you do not donate to aid agencies, you are doing something wrong" 
(Singer, 2009, pp. 15-16). It is worth noticing that utilitarian thinking is not necessary to accept this argument.

The book The Live You Can Save was a highpoint of sorts for Singer's philosophy and one of the canonical positions for effective altruism, although the idea was not named there, the philosophical argument underlying it was formulated. In this book he argues that we can effectively help people living in extreme poverty by donating to some organizations, which he recommends and also that it is the duty of each of us to do so. With his friends, he gathered some people around the idea, using the internet webpage thelifeyoucansave.org (which is now one of the pages gathering effective altruists and recommending the most effective charity organizations to support). Knowing that conclusions of his argument are not suitable for most people (including himself), Singer does not advise promoting the most radical way (objective moral standard). Instead, he proposes to move towards a good direction and to pledge (on thelifeyoucansave.org) a certain amount of money, calculated personally according to how much one earns with regard to the costs of living. For people with an average income it should be around $10 \%$. It is a lot of money, but far less than one should give according to the objective moral standard presented by Singer in his argument. The book announced effective altruism in a sense, as it clearly stated that eradicating extreme poverty is possible within resources we have when we apply reason to aiding. Also, some reasoning on how to select the most effective charities and arguments on why it is our duty to aid and why human nature prevents us from fulfilling objective moral standards are presented. All these are key points in reflections on effective altruism and are Singer's clear contribution to the idea and movement.

\section{Effective Altruism - the beginning}

The ideas of Singer and other Utilitarians were gathering people with great awareness of their impact on the world and the moral duties flowing from it. The time had come to move forward and start an ethical revolution. A reflection on how to make our charity efforts more effective was started. But not only recent books in ethics started effective altruism; the beginning of our century is the era of rapid development of communication technologies. It made it possible to transfer resources directly to those in need. I may buy a bottle of water here and send it but I can also transfer some money to a person in another country and he could buy water. Now we can help with just a few clicks - by transferring our money to a proper organization.

There used to be, however, a lot of distrust towards charity organizations. Many thinkers argued that charity does not help people, perhaps even harms them, also it was believed to be a great waste of precious resources. Donors never knew what the effects of their money transfers were. However, in the last 15 years, a substantive amount of scientific research comparing or evaluating the effectiveness of charity programs appeared. It was shown that we tend to support programmes which sound nice to us rather than those which really help. A very popular program Playpumps was proven to be ineffective (if not harmful, see MacAskill, 2015a, pp. 1-18). This research helped to create a new branch of charity - 'meta charity', which evaluates the targets of charity, aid programs or organizations. There are meta charity organizations which publish lists of charities worth supporting. Meta charity organizations which follow the rules of effective altruism ${ }^{3}$ are becoming more and more popular every year, as they simplify making "credible" donations.

Also, humanity is wealthier and wealthier. People in affluent nations have a lot, feel secure and therefore can give more. The number of people living in extreme poverty is now decreasing. As Singer points out, in the past it was unclear if we could eradicate extreme

\footnotetext{
${ }^{3}$ See following web sites: Givingwhatwecan.org, Thelifeyoucansave.org, Givewell.org.
} 
poverty, but now we see the top of this hill (Singer, 2009, p. xi), we need just small changes in our choices.

The development of ethical reflection, especially within utilitarianism, progress in research measuring the effectiveness of charity, increasing the affluence of the richest nations and development of technology have made it possible for effective altruism to appear. In the next part, an attempt to describe the movement is made.

\section{Effective altruism}

To be an Effective Altruist, one must stand in opposition to the contemporary, consumerism mentality. Instead of a pursuit of utilizing as many goods as possible, an effective altruist must decide to live modestly, taking what they need instead of what they might want. Changes in one's life can be very deep, if they are moved by ethical ideals. A good example could be ethically-motivated modifications in shopping priorities: an effective altruist tries to buy things that he/she needs and does not focus on "other qualities" that might impress neighbours, but are not really necessary. Consider cars. Everyday observations suggest that most people use cars to go to work, to do shopping and to take children to school. Longer car journeys are rather exceptional. We might rationally assume that real need for a 4-wheel drive is very rare for a person living in a city. Also, it is easy to notice that there is usually only one person in a car. Knowing the needs, we would expect that the majority of cars parked in front of shops or schools will be relatively small, simple and powered by engines with good fuel economy. Nevertheless, what we can discover without deep research is that our cities are packed with large, expensive cars, of very high performance, with big engines and very comfortable interiors. It seems that the cars most people possess do not match their needs. An effective altruist will think about it and notice that if one can afford a limousine, but buys a small hatchback, then there is some money left and that money can be donated to an effective organization. A similar conclusion is to be drawn when considering other market-choices.

The more money you save, the more you can give. Of course, Singer and others don't encourage us to live only to give. According to him, we should give a significant amount of money, but only if we can do it without sacrificing something that is really important like education of our children or having children, or our health. Singer believes that most effective altruists "are somewhere in the continuum between a minimally acceptable ethical life and a fully ethical life" (Singer, 2015, p. viii). They do not live a fully ethical life (a life according to objective moral standards), so they do not donate everything less important than the life of a person in terms of a purely rational utilitarian calculation. However, they do not blame themselves for not being fully rational, they "focus on the good they are doing" (Singer, 2015, p. viii). For Singer, it is good enough to look carefully at the budget and decide how much of it can be donated. Helping others is our duty but it cannot make our lives unhappy, quite the opposite - an effective altruist should be moved by the happiness brought about by doing something significant for others. And as effective altruists claim, the good achieved by donations to the most effective charity organizations can be very significant, which can be estimated on the webpage givingwhatwecan.org when a visitor of a webpage inserts his yearly income into a special form, a page algorithm compares it to the rest of the world and shows how people living in extreme poverty would benefit if $10 \%$ was donated to support the most effective charity organizations.

As one of the main aims of Effective Altruism is eliminating the unnecessary suffering of animals; hence effective altruists stand in opposition to meat-eating culture. They recognize that our dietary choices matter to animals and can make a great difference in food production (MacAskill, 2015a, pp. 107-108). To help animals, they make steps towards a vegan diet, starting with eliminating meat that is a product of factory farming, by eliminating meat and finally other non-vegan products. But not all effective altruists decide to be strict vegans. 
Avoiding food with small amounts of dairy products or eggs costs a lot of time, energy and money that could be better used elsewhere and may also discourage people from being vegan at all (Singer, 2015, p. 69).

It is important to emphasize that effective altruists do not support just any charity organizations. An important discovery made by the philosopher William MacAskill is that aiding is also an investment (MacAskill, 2015a, p.13). Normally, when we invest our money, we think about it more or less carefully and try to maximize the benefits. Imagine a person entering a random shop with $€ 100$ who gives the money to the shop assistant and asks to fill their bags with food. She/he does not look at prices, calories or even if what the shop assistant puts into the bag would really satisfy their nutritional needs. She/he does not even think about the possibility that what the bag contains might be harmful. We would probably not risk taking the attitude of such a careless person. However, when it comes to aiding, this is what we do. When we give money to a random beggar, we have no idea what the effects of our help would be and we may suspect that it is not the best thing that can be done with our money. Similarly, this is what happens when we support a random charity programme because we were convinced by a talkative person on the street or by a letter that appeals to our emotions. For effective altruists, aiding is like any other investment, so only hard data should be convincing. And by comparing hard data, the best programmes and the best aid organizations can be selected. Choosing how to help is not a matter of the heart but of mathematics.

Another key idea of Effective Altruism is modifying one's career according to ethical motivation. In Effective Altruism, though, ethical motivation means choosing the most appropriate career considering the good that it can bring, hence, the obvious strategy for all people is the earn-to-give strategy. To do the most good, one should first consider a job with the highest earnings. Singer often recalls his student Matt, who was a very talented student of philosophy and could continue as an academic but he calculated that as an academic he could save around one hundred lives during his lifetime and a job on Wall Street would probably enable him to do that in a year. Moved by his calculation, he decided to try to work on Wall Street after graduation. The difference in wages made it possible for Matt to save a hundred lives in the first years of his career (Singer, 2015, pp. 3-4). Naturally, not everyone is talented enough to get a job on Wall Street and the number of the best paid jobs is limited, but in a moment of life when one can change their career, it should be considered to take a better paid job. Some people may have a good reason to take a different career path: the career of a researcher in vital areas like medicine or making meat without animals, direct work in effective charities, advocacy for effective altruism or working in meta-charities. Which of these is a good choice depends on the person but should be considered on the basis of rational reflection. Effective altruists tend to reject as irrational the popular career choice advice: "follow your passion" (MacAskill, 2015a, pp. 181-221). One of the web pages of paramount importance to effective altruism is 80000hours.org. The name of the page refers to approximate time we spend at work during our entire life. Visitors to this page may find some clues on ethical career choices.

Ethical motivation urges effective altruists to make changes in their habits, the way they spend money, the way they spend time, the way they work. Nevertheless, many of them decide to give literally a part of themselves. One of the ways is giving blood or bone marrow, but some effective altruists are more radical. Donating one of our non-regenerative, double organs (eye, kidney) may make our life less comfortable, but can have a significant impact on the lives of other people. Although donations of regenerative parts of body are common to effective altruists and the number of anonymous organ donors increases every year (Singer, 2015, p. 71) this radical approach to giving a part of oneself is considered heroic. 
The outline of Effective altruism was focused on five points that appear to be the most important and characteristic for the movement: life choices that make it possible to give more, tension between honouring objective moral standards and human nature that makes it hard to respect it, concern about every sentient creature, treating charity like an investment and applying reason to it and ethically motivated career choices. Space considerations does not allow further explanation in more detail here or describe other important ideas of Effective Altruism, but it has been done in two recent books by Singer and MacAskill (Singer, 2015; MacAskill, 2015a). It may be noticed that ethical guidelines of Effective Altruism seem to be difficult for an ordinary man, as they are often counterintuitive and encourage rejecting consumerism and focusing on self-interest, which people in affluent countries are more used to. Although the movement is growing, it is hard to believe that all people or even the majority would share these views. It seems that joining Effective Altruists is hard in the most affluent countries. In the last part, some facts and doubts will be elaborated on that suggest additional difficulties to overcome in implementing the idea, especially in less-wealthy countries.

\section{Effective altruism and less-wealthy nations}

Effective altruism seems to be a reasonable ethical approach for people living in the most affluent countries. They may follow it and sacrifice very little from their wealth, as their needs are satisfied and they do not benefit very much from additional money. Crumbs from their tables are lunches for people living in extreme poverty. Effective Altruism has been criticized by some philosophers (Gray, 2015), the critique focuses mainly on difficulties typical for utilitarian ethics or the probability of following ethics built from the point of view of an impartial observer. Jeff MacMahan has recently referred and replied to this critique (MacMahan, 2016).

There is also a doubt about the relationship between effective altruism and consumerism. It is possible to perceive effective altruism with consumerists' logic. As effective altruism grew on utilitarianism, motivation of the act is not important as long as it does not affect the consequences. However, it is possible to treat donating to effective charity organizations as another luxury service. Something that was never done before or something that makes us feel more trendy. Donating takes very little effort nowadays. Also, Singer intentionally encourages donors to "sound a trumpet when we give to the poor" as then other people would follow. He believes that we tend to do what others from our reference group do (Singer, 2009, pp. 6466). The risk is that when Effective Altruism ceases to be fashionable, the number of donations will decrease. However, even if Effective Altruism remains a part of consumerist logic, for Utilitarians it is important that it does its job - some money that would otherwise be spend to satisfy the sophisticated needs of people from affluent countries - has already been transferred to effective charities. The motivation for donors does not change the fact that they give and the lives of people living in extreme conditions significantly changes.

Effective altruism also shares all the difficulties that non-consequentialists see in consequentialism and especially utilitarianism. The utilitarian notion of good appears to be understood in a hedonistic sense, which would seem too narrow for people who follow, for example, Christianity-inspired ethics, which is still an important ethical position in the countries of Central and Eastern Europe. It is an opportunity to enter the debate on effective altruism and propose a broader notion of good. In addition, there is a risk of turning an effective altruist into a machine for the redistribution of wealth - a means rather than an end. This is something unacceptable to the followers of Kant, whose ideas are still very prominent in ethical debates, and should also be more broadly discussed (Singer, 2015, pp. 45-54). The limits of this paper do not allow deeper investigation of this interesting topic. 
A philosophical critique of Effective Altruism is addressed to all its followers. To achieve the aim of this paper, possible difficulties for Effective Altruism in the countries of Eastern and Central Europe will be focused on. An attempt will be made to address these issues and show the way Effective Altruism can be developed in less-wealthy countries.

Although focus is on the countries of Eastern and Central Europe, especially on Poland and Slovakia, the conclusions apply to other countries in similar economic and social situation. It must be noted that countries like Poland or Slovakia have made great progress towards affluence in the last 20-25 years, but from the perspective of the United Kingdom or the United States they remain poor countries. As was emphasized in this paper, rising affluence was one of the most important circumstances that allowed Effective Altruism to appear.

The level of affluence of the Polish is of course very high if we compare it with people living in extreme poverty or even with the global average income. The average yearly income of a single person in Poland is about 36000 PLN after tax (ca. 8200 EUR) which, according to Givingwhatwecan, locates him/her among the top $8.6 \%$ of the world's richest people with an income more than 13 times higher than the global average. A person earning the minimum wage will have a yearly income of 16260 PLN after tax (ca 3700 EUR) which locates him/her among the world's richest $18.3 \%$ of people, earning six times more than the global average. If one earns the average yearly income and in his/her household there are 3 more persons, then he/she is among the richest $21 \%$ of people with 5 times the global average. ${ }^{4}$ Basing ideas only on numbers appears heartless, as people earning the minimum wage, even in the most wealthy countries, cannot really feel they are among the top richest people. Probably it is more important to see what one can do with the earned money. People from the countries of Central and Eastern Europe spend significantly more on food (in 2015 Poland: 16.9\%, Slovakia $17.8 \%$ and some other countries reaching nearly $30 \%$ of the average household's income) than the most affluent countries of Western Europe (United Kingdom 8.3\%, Germany $10.5 \%$ of the average household's income) (Eurostat, 2016a). Assuming similar nutritional needs, this example suggests that people in less-wealthy countries find it expensive to satisfy basic needs.

Instead of statistics referring to income, one can focus on people's opinion. Eurobarometer estimated the opinion of European countries' citizens on the current situation in the economy, and although the growth of wealth in the countries of Eastern and Central Europe (EU members) is significant, still more than half of the people evaluate the economy as bad (Eurobarometer, 2015, pp. 19-20) also, most of them believe that major state problems are related to the economy, fewer than $5 \%$ of them point to environmental problems (Eurobarometer, 2015, pp. 18). It confirms the focus on basic needs, compared to people from the most affluent countries.

Considering the economic situation of Poland and Slovakia we may assume that it will be more difficult (although not impossible) for citizens of these countries to make life changes that would allow for making greater donations. Visiting Warsaw or Bratislava gives evidences that many people in Central and Eastern Europe enjoy luxuries in their lives. On the other hand, there are still too many people there who struggle to live from day to day. They may be employed, they do not face extreme poverty nor are they threatened with death from easily preventable diseases, but they can be marginalized in their societies, sometimes trapped with bank loans, earning just enough for food and repayments. People living in such conditions do not need additional motivation to get a better paid job it is just out of the range of their capabilities. They live modestly because they have to, small (and often old) cars and houses are not their moral choice but a necessity.

\footnotetext{
${ }^{4}$ This paragraph contains conclusions of simulations made by the internet calculator "How Rich Am I?"; a part of the webpage Givingwhatwecan. Necessary data were taken from government webpage: Główny Urząd Statystyczny (Central Statistical Office of Poland), accessed $14^{\text {th }}$ November, 2016.
} 


\section{Conclusion}

These economic circumstances may lead to the conclusion that Effective Altruism is an exclusive ethics for the rich (in Central and Eastern Europe). It is obvious that not living in appropriate conditions may render it more difficult to make a great impact with the donated money, but it does not mean that one cannot be an effective altruist. The obvious limitation is that the earn-to-give strategy may be difficult to apply. Even if we can donate only a small amount of money to charity it is better to give it to an effective organization than to a noneffective one (as long as the cost of processing the donation does not exceed it). Furthermore, one can always analyse a household's budget and try to discover those areas where some money can be saved and donated. In addition, effective altruism is not limited to transferring money, one can "donate" his time or skills (by working in charity or meta-charity). Being convinced about effective altruism and sharing the idea can do more good than large donations since if you convince two people you triple your impact (cf. Singer, 2015, pp. 5556). Also, effective altruists claim that helping others with the resources we have, be it time or skills or money, gives the life meaning and happiness. For less-wealthy people who cannot achieve happiness proposed by consumerism, Effective Altruism is more promising as it does not tie achieving happiness with earning a lot of money. A person with small earnings will do less good to others by his or her donations, but giving what he or she can, will do give his or her life meaning in the same manner as a richer person.

Effective Altruism (EA) wants to be global movement but in fact it was started and developed in only the most affluent countries. The countries of Eastern and Central Europe have their own representatives in the EA community, but the development of local communities is very poor. In Poland there are only few people popularizing the idea of Effective Altruism, only one book has been translated and there is only one page devoted to it. Although ideas can spread very quickly nowadays, Effective Altruism appears to be barely known in Central and Eastern Europe. Without more popularization, it would be hard to encourage a significant number of people to follow the guidelines proposed by Effective Altruism. It can be argued that advocating for Effective Altruism is a good way to do the most good with the available resources. Countries of Eastern and Central Europe are getting more and more affluent, subsequent generations are richer than their predecessors. Advocating for this model of altruism, creating a culture of effective giving may not bring immediate impact, but will bear fruit in the future. By advocating now, when Effective Altruism is new and unknown, one can have an impressive impact, because it might start a chain of advocacy, and lead to more donations in the future, when social and economic circumstances in Central and Eastern Europe might be better.

Effective altruism is a new movement and like many new endeavours, faces some teething problems. It is a fact that it positively changes the world and unlike most philosophical ideas, changes people's lives and redirects a lot of time and money. It is not fixed once and for all, it is changing and developing due to the discussions of people who are concerned about the fate of the inhabitants of our planet and are convinced that saving them from extreme poverty or unnecessary pain is their duty. In my view the task for a philosopher is to notice the weaknesses of Effective Altruism but also to enter the discussion on how to do the most good. And to do it.

Jakub Synowiec is a lecturer at the Faculty of Philosophy, Pontifical University of John Paul II in Krakow. His main research interests are: meta-ethics, ethical argumentation, effective altruism, the ethics of Peter Singer, personalism. He has written several articles and one book: Model argumentacji etycznej $w$ etyce personalistycznej Karola Wojtyly $i$ Tadeusza Stycznia 
[The model of ethical argumentation in the personalistic ethics of Karol Wojtyta and Tadeusz Styczeń], 2014.

\section{Corresponding author:}

Jakub Synowiec, Wydział Filozoficzny, Uniwersytet Papieski Jana Pawła II w Krakowie, U1. Kanonicza 9, 31-002 Kraków (Poland)

Email: jakub.synowiec@upjp2.edu.pl

\section{References}

BENTHAM, J. (1789): An Introduction to Principles of Morals and Legislation. London: T. Payne.

BOSTROM, N. (2013): Existential Risk Prevention as Global Priority. In: Global Policy, 4(1), pp. 15-31.

GRAY, J. (2015): How \& How Not to Be Good, [online] [Retrieved September 30, 2016]. Available at: http://www.nybooks.com/articles/2015/05/21/how-and-how-not-to-be-good/

EUROBAROMETER (2015): Standard Eurobarometer 83, Spring 2015 [online] [Retrieved November 12, 2016].

Available at: http://ec.europa.eu/public_opinion/archives/eb/eb83/eb83_en.htm EUROSTAT (2016a): Final consumption expenditure of households, by consumption purpose, code: tsdpc520, [online] [Retrieved November 12, 2016].

Available at: http://ec.europa.eu/eurostat/en/web/products-datasets/-/TSDPC520

EUROSTAT (2016b): GDP per capita in PPS, code: tec00114, [online] [Retrieved November 12, 2016], Available at: http://ec.europa.eu/eurostat/web/products-datasets/-/tec00114

MACASKILL, W. (2015a): Doing Good Better London: Guardian books.

MACASKILL, W. (2015b): What is Effective Altruism. In: R. Carey (ed.): The Effective Altruism Handbook. Oxford: Centre for Effective Altruism, pp. 11-13.

MACMAHAN, J. (2016): Philosophical Critiques of Effective Altruism, [online] [Retrieved September 30, 2016]. Available at: http://jeffersonmcmahan.com/wp-content/uploads/ 2012/11/Philosophical-Critiques-of-Effective-Altruism-refs-in-text.pdf

MUEHLHAUSER, L. (2015): Four Focus Areas of Effective Altruism. In: R. Carey (ed.): The Effective Altruism Handbook. Oxford: Centre for Effective Altruism, pp. 99-106.

SINGER, P. (1975): Animal Liberation. New York: HarperCollins.

SINGER, P. (1972): Famine, Affluence and Morality. In: Philosophy and Public Affairs, 1(3), pp. 229-243.

SINGER, P. (1979): Practical Ethics. Cambridge: Cambridge University Press.

SINGER, P. (2009): The Life You Can Save. London: Picador.

SINGER, P. (2015): The Most Good You Can do New Haven \& London: Yale University

Press.

SINGER, P. (2000): Writings on an Ethical Life. New York: HarperCollins.

UNGER, P. (1996): Living High or Letting Die. New York: Oxford University Press. 